\title{
SSLASPA: The Beginning
}

\author{
James H. Conn \\ Central Missouri State University
}

This article first appeared in JLAS Volume 11, Winter 2001.

The conferences sponsored by the Society for the Study of Legal Aspects of Sport and Physical Activity (SSLASPA) over the years have used a wealth of expertise to educate the members with timely subject matter. Several members have requested that I provide my recollection of our first SSLASPA conference for the archives.

To gain a succinct understanding of the origination of today's SSLASPA, one must understand the history behind the place and origin of its first conference. The making of SSLASPA finds roots in the interest that John Merriman and I held for the law and its profound effect on the operations of physical education, fitness, and sport programs, in addition to the preparations of individuals entering the profession.

The intent of this article is threefold. First, it will remind readers of the concerns that John Merriman and I had for judicial intervention and its impact upon the conduct of our profession as teachers and scholars in sports, physical education and recreation. Next, it will recreate the organization of the first conference. Finally, it will also present the highlights of the first conference.

\section{Early Concerns of the Law and its Effects on Programs}

In the later '70s and early '80s I served as an athletic director, and football and basketball coach, in a small school district in the state of Washington. During that time, a sophomore running back named Chris Thompson suffered a quadriplegic football injury while representing Seattle West High School. In 1983, a trial court rendered the Seattle School District liable for a number of professional failures. However, one of those deficiencies rested with the failure of the district to warn Chris and his mother that he could suffer permanent injury (including paraplegia) while playing football. The jury verdict caused a commotion throughout the educational and interscholastic athletic communities in the state of Washington.

James H. Conn is the former Department Chair in Physical Education at Central Missouri State University. He currently teaches one undergraduate and one graduate course in legal issues and one graduate course in risk management. He has taught, coached, and served as an administrator in public schools and universities for 32 years. Dr. Conn has published two books and written numerous articles on risk management and legal issues in sport. He regularly conducts in-service in school districts and frequently speaks at national, regional, and district conventions. 
Immediately, members of school boards, superintendents, and other administrators demanded that their athletic directors and coaches formulate written operational procedures and safeguards for managing the risks of their respective programs. Feverishly, Washington state high school athletic directors and coaches articulated warning statements, job descriptions and other information for the purpose of documenting risk management procedures for interscholastic sport programs. That experience profoundly shaped my professional life.

Subsequent employment in 1986 at Valdosta State University (then called Valdosta State College) continued to foster my interest in risk management strategies. During the spring semester of 1987, I shared my respect for legal findings and its impact on the operations of physical education and sport programs with Dr. John Merriman, my department chair. After discussing the professional concerns I had for the plight of many coaches, teachers, and recreation personnel, John displayed an immediate excitement. At that moment I was able to convince John of the need for providing physical education, sport and recreation professionals with information on the current state of affairs of risk management and other legal aspects of sport.

Later, John reiterated to me that his previous interest in sport sociology registered an earlier awareness of athletic abuses, but oftentimes failed to generate an effective way to correct such scurrilous behavior. My comments clearly expressed that "legal" education and risk management strategies directed toward school and college personnel would well serve them and the profession and brand a safer participation experience in sport. John and I agreed that the profession remained responsible for providing forums for professionals to share recent legal findings and discuss their effect on program operations.

To this point, professionals experienced difficulty in obtaining legal information that would help them safely conduct their programs. Professionals read occasional law-connected articles that were juxtaposed in a myriad of other articles in professional journals. In addition, the national conventions [American Alliance for Health, Physical Education, Recreation and Dance (AAHPERD), National Intramural-Recreational Sports Association (NIRSA), etc.] infrequently sprinkled legal related presentations in their meetings. Not to be overlooked, the textbooks, journals, and quarterly publications reported legal findings but by the time many of these publications went to print, the law had changed.

During the spring of 1987 the Department of Health, Physical Education, and Athletics at Valdosta State University supported my attendance at a sport and law symposium in Atlanta. Dr. Herb Appenzeller and E. Thomas Ross, a practicing attorney, were the presenters. Several public school and recreation personnel attended the meetings. The primary focus of the conference centered on negligent claims against professionals and organizations.

The symposium reinforced my thoughts toward hosting and sponsoring a comprehensive national conference that primarily focused on the law and its effect on the operations of physical education, sport and recreational programs. John was convinced that the timing was right. Consequently, John and I agreed to codirect our own conference. Our survey suggested that an annual two or three day conference related solely to legal issues in sport was simply unavailable at the time. Subsequently, we sensed the need to bring about a more informed and concerned profession. Hindsight suggests a timely idea. The preparation for the conference proved eventful. 


\section{Preparation of the First Conference}

To imply that John and I undertook this project with naïveté would be kindness. Enthusiastic? Yes. Willing to work hard? Yes. Knowledgeable as to how to do it? No. Did we receive encouragement? Yes. We scrounged for seed money. The budget from the Department of Health and Physical Education absorbed the cost of the correspondence. Dr. F. D. Toth, Dean of the College of Education at Valdosta State University assumed the phone costs. The Hughston Clinic in Columbus, Georgia submitted $\$ 500.00$ to the conference and an insurance company in Kansas City, Missouri funded the banquet. The department absorbed the secretarial needs.

John and I advertised the conference in the Chronicle of Higher Education and NASPE News. I located names and addresses in the Gold Book and mailed in excess of 200 personal invitations to college and university professors listed as involved in sport law. I also mailed another 500 invitations to school boards and public school personnel in Alabama, Georgia, South Carolina and Florida. The invitations and advertisements included requests for their presence with an option of delivering a paper.

Unfortunately, a few a people failed to understand what John and I expected to accomplish. Those individuals refused to present and/or attend unless the conference granted them an honorarium and their expenses. Hapless, John and I did not possess the "start-up" funds or seed money for uninvited presenters. Fortunately, so many of the present membership believed in the idea, saw the potential of the conference, and wanted to be a part of it, that they submitted excellent papers and laid the foundation for a solid conference program. The remaining section of the paper underscores the first conference.

\section{Highlights of the First Conference}

Highlights permeated the conference. John and I titled the first program "Sport, Physical Education and Law Conference." The remaining portion of the paper focuses on the site, registration fees, attendees, agenda, financial summary, and publications of the proceedings.

\section{Site}

John and I scheduled the first Sport, Physical Education, Recreation and Law Conference in the spring, March 17-19, 1988 (Thursday, Friday, and Saturday). We conducted the conference at the Villas-By-the-Sea Resort in Jekyll Island, Georgia. The key contact person at the Villas, Ms. Sheila Duncan, arranged the accommodations and planned the lunches and banquet.

\section{Registration Fees}

John and I arbitrarily assigned a preconference registration fee of $\$ 100$ and an on-site registration fee of $\$ 125$. 


\section{Attendees}

Approximately 75 professionals attended the first conference. The receipt book, which contained the verification of those who paid to attend the conference, remains lost. Those in attendance represented a cross section of professionals that included school board members, superintendents, principals, physical education teachers, athletic directors, and college professors.

\section{Agenda}

The conference agenda included the days and times for conference registration, meals, keynote speakers, sessions, and other presenters.

\section{Meals}

The convention registration fee included a luncheon and evening banquet dinner. The luncheon menu consisted of soup, sandwich, fruit salad, and a dessert of apple strudel and ice cream. The banquet dinner included roast beef, baked potato, steamed veggies, and green salad, with key lime pie for dessert. The luncheon cost $\$ 10.50$ and the banquet $\$ 14.75$.

\section{Keynote Speakers}

John and I invited six recognized scholars and/or professionals in sport and law to present keynote addresses to the conference. We thought these individuals would positively influence the attendance. The invited speakers and topics were as follows: 1) Barbara Twardus, "Life After Litigation: The Chris Thompson Case"; 2) Jean Perry, "Administrative Responsibility in Dealing with and Preventing Litigation"; 3) Nathaniel Erhlich, "Legal Responsibility Related to the Training Room"; 4) George Sage, "Interrelationships of Society and Sport Law"; 5) John Massengale, "Summary Comments and a Look at the Future of Sport Law"; and 6) Bill Judge, "A Legal Perspective of Intercollegiate and Interscholastic Athletics."

\section{Paper Presenters}

Of course these were not the only speakers for the conference. The directors advertised for a call for papers/presentations. A total of 31 presentations were submitted and John and I chose 25. The other paper presenters at the first convention were John Drowatzky, John Merrima, Jim Conn, Susan Cross Lipnickey, Rod Walters, Ron Kanoy, Michael Kramer, Michael Livingston, Jack Razor, Neil Thueson, Dick Moriarty, Marge Holman, Jim Smith, Elyzabeth Holford, Charles Espinoza, Millard Fisher, Richard Feldman, Tom Bryant, Robin Chambers, Lynn Gaskin, David Mathews, Michael Reese, Harold Bishop, Lanny Gamble, and Bernard P. Maloy.

\section{Sessions}

The first conference generated eight sessions. All sessions were carried on in the Villas-by-the-Seas Conference Center. The attendees listened to the first two sessions during the afternoon and evening of Thursday, March 17, 1988. On Friday, 
March 18, the third (Friday morning), fourth (Friday afternoon), and fifth (Friday evening) sessions were held. The conference concluded with three more sessions on Saturday, March 19 in the morning, afternoon, and evening. Those eight sessions produced 26 presentations. A presider was assigned for each session, and attendees were asked to provide an assessment of each presentation and leave their responses with the presider. Finally, each invited paper or presenter consented to videotaping.

\section{Financial Summary}

The financial goal of the conference was to break even. John and I decided to invite prominent scholars from our profession. Being novices in this business, John thought a fair honorarium for keynote speakers (invited speakers) would be $\$ 1,500.00$ each. We anticipated that the conference registration fee would offset the honorarium, luncheon, banquet, and folders. Financing for the conference did not come easy. John Merriman personally financed the conference from his own savings.

Still, the first conference was a financial bust-in the hole nearly $\$ 6,000.00$. Unfortunately, we overestimated the lure of the conference and anticipated 150 attendees. Two of the speakers offered to present their work just for expenses (George Sage and John Massengale) but we stayed with the original agreement.

Obviously the first conference was not a financial boost to either of our egos. Naturally, as John was hurting over the financial matters, he claimed that he would no longer financially support the conference. However, I decided that I would organize the conference. My attempt was to provide an excellent service to the attendees as well as bailing John out from under the $\$ 6,000.00$ financial burden. So, we designed future conferences to make a profit.

After the first year, John and I decided that those kinds of honoraria remained unnecessary and we began to make a profit. As soon as the $\$ 6,000.00$ was paid back we had enough to start a journal and have it printed.

\section{Proceedings}

The printing of the proceedings from the first conference remained a mess because we lacked the time or personnel to edit papers. In addition, we had to take what was submitted. We did not have funds to print the proceedings and so we just ran them off on a copier. The proceedings were the only thing we ever were embarrassed about.

\section{Reflections}

John Merriman and I remain happy that we embarked upon this enterprise. We have met wonderful, professional and supportive people. The key to the success we have all enjoyed is the low-keyed, friendly atmosphere that has brought so many people back to the conferences again and again, and has made SSLASPA an organization that continues to thrive. 